\title{
Regionalization of the world as the key to sustainable future
}

\author{
Svitlana Radziyevska ${ }^{1, *}$, and Ivan $\mathrm{Us}^{2}$ \\ ${ }^{1}$ National Academy of Management, Department for International Economic Relations, 15 Ushynskoho Str., Kyiv, 03151, Ukraine \\ ${ }^{2}$ The National Institute for Strategic Studies, Department of Foreign Economic Policy, 7-a Pyrogova Str., Kyiv, 01030, Ukraine
}

\begin{abstract}
Globalization is viewed not only as the objective, but also as the subjective process, the current version of which requires adjustments since it is characterized by the increasing inequalities and instability, causing conflicts worldwide, pushing regional groups towards confrontations. Globalization is to be directed for achieving the equitable levels of development across the globe for which it is suggested to establish the situational governing board as the common platform for collaboration between the regional blocs for global economy regulation. The notions of the regional state and the global/planetary state are introduced. The interdependence between regionalization and globalization is thoroughly analysed, which results is the explanation of the logic behind the process of the multipolar world formation as opposed to the unipolar one. The main points are illustrated by the facts from the EU integration history, WTO practice, the calculated indicators of the major thirteen regional integration groupings covering Europe, Asia, North, South America, Africa, two transregional organizations - Regional Comprehensive Economic Partnership, Transatlantic Trade and Investment Partnership, as well as the USA, Developed economies of Europe, China. The contribution to the study of regionalism as the boosting phenomenon shaping the development of the world allowed to conclude that regionalization is critical for the sustainable future of the world.
\end{abstract}

\section{Introduction}

Regionalization as the formation of blocs of states in one form or another has always been inherent to the development of the world. From the historical perspective the initiation of the regionalization process played its brilliant role in uniting and strengthening Europe in the $50 \mathrm{~s}$ of the $20^{\text {th }}$ century where for ages attempts had been made to create regions of peace, prosperity, and cooperation, thereby eliminating the causes of tensions and conflicts between some states [1].

After the end of the Cold War, the world became more ideologically homogeneous. There were subsequent attempts to build systems of collective security, and even elements of world statehood - through human rights or economic treaties and in the functionally differentiated sphere of security [2, p. 3]. Despite those attempts, notwithstanding globalizing forces and the emergence of elements of global constitutionalism and security, the world has been reverting to nationalist statism, militarized conflicts and arms races. Lately, the shift in the global power balance has accelerated, the international system has come under strain, and the competition between major countries has intensified.

In the mentioned above context the general number of regional agreements had increased quite significantly, from 445 in 2011 to 669 in 2018. An evolution of the depth of regional integration is noticeable as well, as listed in 2018 by the World Trade Organization (WTO). In fact, 29 customs unions (only 9 in 2011) and 150 Economic Integration Agreements have entered into force. About $60 \%$ are still composed of Free Trade Agreements (FTA; 250) and Preferential Trade Agreements (23). Moreover, if $50 \%$ of those regional agreements were bilateral in $2011,66 \%$ are plurilateral and only $33 \%$ bilateral in 2018 . In the end, 175 of those agreements are cross-regional [3].

Notable increase in the number of integration projects in different regions of the world from the mid1980s transformed regionalism into global phenomenon full of substantial and organizational variations and an important element of the overall architecture of world economy and safety [4].

Thus, it is important to ensure that the regionalization processes are directed to contribute to the sustainable development which is to remain the prevailing trend for the future of the world.

The objective of the paper is twofold:

first, to reveal the interdependence between the regionalization and the globalization processes, to explain the logic behind the process of the multipolar world formation;

second, to demonstrate that the sustainable development on the global level requires attaining the state of unity in the diversity, the peaceful co-existence of the major states and regional blocs, and to show that the sustainable development of the regional groups ensures the sustainable future of the world.

The scientific novelty of the research:

1) the notions of the regional state and the global/planetary state are introduced;

* Corresponding author: svitrad98@ukr.net 
2) the dialectical relationship between regionalization and globalization is revealed;

3) the theoretical results are confirmed by the calculations of indicators taken from UNCTAD handbooks of statistics, and it is proved that the further integration of the leading regional blocs and/or major states of the world economy is highly unlikely.

\section{Globalization and global economy}

\subsection{Globalization as the objective and subjective process contributing to sustainable development of the world economy}

The analysis of many definitions of the term "globalization" allows us to conclude that although the globalization is the objective process, most of the scientists believe that the current version of globalization requires adjustments and thereby recognize the existence of the alternative ways of its further evolving.

For the illustration of the above-mentioned point the brief information on some approaches to the notion is given in table 1 .

Table 1. Some approaches to the concept of globalization in scientific literature.

\begin{tabular}{|c|c|}
\hline Description & Scholars \\
\hline $\begin{array}{l}\text { Globalization - in the simplest sense - an } \\
\text { umbrella concept that seeks to capture the } \\
\text { growing interconnectedness and integration of } \\
\text { human society at the planetary scale. }\end{array}$ & A. Jones [5] \\
\hline $\begin{array}{l}\text { Globalization is variously } \\
\text { mean internationalization, }\end{array} \begin{array}{r}\text { liberalization, } \\
\text { universalization, and planetarization. } \\
\text { "Globalization" - with its connotations of a } \\
\text { development, a process, a trend, and a change - } \\
\text { is a relatively new word, coming into use during } \\
\text { the latter part of the 20th century. }\end{array}$ & $\begin{array}{l}\text { R. Robertson, } \\
\text { J. Scholte [6] }\end{array}$ \\
\hline $\begin{array}{l}\text { The term 'globalization' often refers to changes } \\
\text { in technologies of communication and } \\
\text { transportation, increasingly internationalized } \\
\text { financial flows and commodity trade, and the } \\
\text { transition from national to world markets as the } \\
\text { main arena for economic competition. The } \\
\text { information age and the stage of global } \\
\text { capitalism are asserted to constitute a new and } \\
\text { qualitatively different historical epoch. }\end{array}$ & \\
\hline $\begin{array}{l}\text { Globalization is largely a coincidental by- } \\
\text { product of the welfare-democratic revolution in } \\
\text { the institutional order in the most advanced } \\
\text { post-war societies. }\end{array}$ & $\begin{array}{l}\text { E. Rieger, } \\
\text { S. Leibfried } \\
{[8]}\end{array}$ \\
\hline $\begin{array}{l}\text { The term is used to refer to what has been called } \\
\text { the 'Washington Consensus', or the } \\
\text { 'globalization project'. }\end{array}$ & $\begin{array}{l}\mathrm{Mc} \\
{[7]}\end{array}$ \\
\hline $\begin{array}{l}\text { A new-hegemonic neoliberal political ideology } \\
\text { that celebrates the victory of capitalism over } \\
\text { socialism and proclaims marketization and } \\
\text { privatization as solutions to the world's } \\
\text { problems. }\end{array}$ & $\begin{array}{l}\text { Ch. Chase- } \\
\text { Dunn, } \\
\text { Yu. Kawano, } \\
\text { B. D. Brewer } \\
{[7]}\end{array}$ \\
\hline
\end{tabular}

As has been described in table 1, globalization is not only the objective, but also the subjective process. Since globalization is the result of the synergistic effect of the many manageable processes (e.g. the peculiarities of the international division of labor, internationalization, regional integration of the world economy, etc.), its directions and intensity can be changed, corrected, managed, completely reformed, and thus it is possible to state that globalization can be governed as well.

\subsection{Global economy formation: pros and cons}

In our opinion, since the globalization is viewed as the objective and subjective process the issue of the formation of global governance and the development of regulatory mechanisms of the global economy becomes relevant, complex, and of vital importance for sustainable development of the world.

Theoretically, if we pursue an objective of establishing the global regulation institution, the formation of the supranational authorities of the regional organizations may be taken as an example, but it is important to keep in mind that the world is much more complex as the object of research in comparison with the region, a part of the world.

The controversial issue of the global economy creation brings up the problem of its polarity.

First of all, if we view globalization as the process of the single holistic planetary state formation, then, secondly, we can state that the final stage of the globalization process is the unipolar world establishment. And then, thirdly, it looks logical to assume that this single world pole is to take up, incorporate, 'inherit' the sovereignty and power of all the nation-states currently existing in the world, which originally formed the Westphalia system and were more or less independent players in terms of building their relations on the international arena. It's important to keep those points in mind.

It should also be mentioned that only in the $20^{\text {th }}$ century the countires began 'to blur' by transferring their sovereignty up and down, and presumably to the global level itself, i.e. to that single pole, contributing to the global economy creation and global government formation.

After the US victory in the Cold War, the postbipolar world became unipolar, formed by the United States and its allies. However, the modern global system is still sometimes called post-bipolar since the world had two poles for more than forty years: the capitalist pole formed by the US and its allies, and the socialist pole formed by the USSR and its allies. To sum up, if the future global economy is to be unipolar, than at this stage of the world development it would highly likely mean approving US as the single pole and retaining their true status as the world leader, or hegemon.

The U.S. are reviewing their role and underline that "in recent years, there has been a shift from the postCold War era to a new international security situation characterized by renewed great power competition between the United States, China, and Russia" and mention that the leading observers refer to the new situation as tripolar or multipolar world [9]. 
As mentioned in the summary of the document, the U.S. role in the world can be described in general terms as consisting of four key elements: global leadership; defense and promotion of the liberal international order; defense and promotion of freedom, democracy, and human rights; and prevention of the emergence of regional hegemons in Eurasia [9].

China, in its turn, emphasizes the need to improve global governance. China believes that guided by a strong commitment to multilateralism, countries should make active efforts to advance the rule of law and democratization of global governance. "Given the governance deficit, peace deficit and development deficit in our world, there is a pressing need to strengthen and improve global governance" [10].

According to B.Hettne and F.Soderbaum, the current global situation needs to be related to the structural transformation of the world, including (a) the move from bipolarity towards a multipolar or perhaps tripolar structure, with a new division of power and new division of labour; (b) the relative decline of American hegemony in combination with a more permissive attitude on the part of the USA towards regionalism; (c) the erosion of the Westphalian nation-state system and the growth of interdependence and 'globalisation'; and the changed attitudes towards neoliberal economic development and associated political system in the developing countries, as well as in the post-communist countries [11].

Under the conditions of a unipolar or bipolar world order it is logical to speak not of the globalization of the world, but of maintaining or opposing the hegemony of one state and its allies or increasing conflict between the two. There is no need to prove that the ties between the West and the East, the US and China, the Western civilization and the other civilizations might become even more tense and could result in confrontations.

It is necessary, before proceeding, to underline that at the end of the second decade of the twenty-first century, the dominant position in the world space is occupied by the Western civilization, the rise of which is largely due to the effects of various factors, e.g. - religious - the spread of Protestantism; political - the democratization of society, the formation of "melting pot" model and the active stage of the regional integration processes; economic - the spread of liberalism. Nevertheless, the logic of the deployment of the historical dynamics of human development indicates the inevitability of changing the current situation through prolonged civilizational conflicts [12, p.75].

In our opinion, to make the universe a safer place for all, to ensure the conflict-free environment in the diversed world, it is of vital importance to establish a multipolar world in which the poles reflect the civilizations and/or economic and political centers, representing the regions, for the sustainable world development. Thus, within the modern scientific debate on the burning issue we would like to agree with the researchers who support the idea that the unipolar world formation, as well as the global government should be rejected, and replaced with the situational governing board for global economy regulation with strong and equal representation of all the existing and soon-to-be- formed poles with equal political rights to make global decisions by consensus.

\section{Interdependence between regionalization and globalization}

\subsection{Fundamental difference between regionalization and globalization}

The analysis of publications shows that there are different views on the interdependence between regionalization and globalization. Some scholars consider regionalization an integral part of globalization, while others - as an alternative to it.

However, according to the definitions, the regionalization process results in the unification, consolidation or integration of some countries, national economies, while the globalization process aims at strengthening interconnectedness and greater unity of all the states of the world. So, it is easy to imagine regionalization as an interaction of two or more countries (or groups of countries), but it is nearly impossible to envisage globalization in the same way, since the concept of globalization extends to all the existing countries and covers all the groups of states. Therefore, the two concepts can be compared and contrasted: but their targets are different in scope - regionalization focuses on some countries, globalization - on all the countries of the world; both globalization and regionalization are the objective and subjective processes, and the former presupposes enhancing the unity of the whole world, the regionalization - the unity of a certain region, just some part of that world.

At the same time the law of the international division of labor forms the basis for both processes. The information and communication technologies shape both processes, but the degree of embrace of internationalization on the global level is higher in comparison with the regional level, and in the regional integration organization it varies within certain limits depending on the depth of coverage as mentioned in the agreement and the type of integration stage. Moreover, regional integration contradicts the main principle of multilateral cooperation, which is the basis of globalization, the principle of equal participation in it for all [13, p. 58].

The scholars suggest the New Regionalism Approach as a broad, open-ended framework for analysing regionalization from a multilevel and comparative perspective in order to understand the complexities of present-day regionalism, and to pay the required attention to the distinction between regional and world approaches [14]. The publications of the regional integration prove that there is an obvious tendency towards studying the feasibility of launching integration blocs, keeping and/or enhancing their sustainability and capacity building, as well as the prospects for their development in general $[15,16,17]$.

Indeed, if we focus on the fact that regionalization segregates a group of countries from the rest of the world, their totality, then we can formally state that 
regionalization weakens the unity of all the countries, leads to certain localization, even deglobalization. This way of thinking would be appropriate if the totality of countries had already been formed/united.

Grzegorz Kolodko, responding to a question about what the future holds for the world, noted that regional integration contributes to, rather than counteracts, the unification of the world and the globalization of the economy. In the future, instead of almost 200 countries and their national economies, we will increasingly be dealing with 10-20 groups that will be confronting political, cultural, social, economic, structural, and institutional issues of the world [18, p. 169-170]. In our view, regionalization leads to advantageous globalization for all if it is carried out in a more balanced and responsible manner, consistently in time and space.

\subsection{Glocalization and the interrelation between regionalization and globalization}

The following point deserves attention: the fragmentation of regional organizations leads to globalization through the process of glocalization, the formation of a single global space by disintegrating/ fragmenting the parts that form it. To make space homogeneous, it is advised to grind the elements that form the whole, so that they become homogeneous mass. The main point here is that the idea of regionalism as an ideology of globalism is justified. The purpose of regionalism is to replace the central role of the nationstate in international relations by a region, obtained either by the fragmentation of the space of the state or by the unification of the territories of several states [19, p. 175-179].

On the one hand, it is hard not to agree with the view on the interrelations between globalization and regionalization, expressed in many modern studies, where it has been argued that globalization is not the process of all-states-inclusive-dynamic-development in general, but that of degradation and further isolation, which increases inequality, poverty, instability, etc. On the other hand, it is certainly true that ideally globalization should aim at achieving equitable levels of development across the globe, i.e. at ensuring the sustainable economic development. According to the Polish sociologist and philosopher Zygmunt Bauman, globalization is not so much about forming a better world, but is about increasing inequalities, enhancing fragmentation, and ultimately is the product of "the individualized society".

Klaus Schwab puts it quite eloquently that "the critical danger is that a hyperconnected world of rising inequality may lead to increasing fragmentation, segregation and social unrest, which in turn creates the conditions for violent extremism. The fourth industrial revolution will change the character of security threats while also influencing shifts of power, which are occurring both geographically, and from state to nonstate actors. Faced with the rise of armed non-state actors within what is already an increasing complex geopolitical landscape, the prospect of establishing a common platform for collaboration around key international security challenges becomes a critical, if more demanding challenge" [20, p.77].

On the one hand, the integration progress on the regional level has been described with the help of the integration stages: free trade area, customs union, common market, economic union, etc. Those stages of integration processes are characterized by the transformation of the role of the nation state in the transition from free trade agreement to full integration, when the functions of nation states are given to the supranational authorities. The transformation of the nation-state in the regional integration grouping is described in detail, the stages of integration are determined, thoroughly reviewed and updated in the scientific literature.

Finally, it should also be noted that regional integration processes have their beginning and end while the globalization processes do not. It is also quite clear to most researchers what the "old" or "new" regionalism is, and what kind of logic stands behind it.

On the other hand, the integration progress on the global level has not been studied properly yet, especially in terms of the global planetary state formation and the changes of its functions in the globalization process. The concept of the global state has not been fully elaborated yet, there are only some approaches to the definition of the global economy, the development stages of which have not been identified yet.

We will add that regional integration processes take place through "top-down" integration and "bottom-up" integration, through state intervention and market forces. It is impossible to speak of globalization in the same sense, because at the global level there is no "top", there is only the interaction of states with formally equal rights, but different economic and military capacities.

However, abstractly it is possible to view the process of globalization as sequential increasing complexity and enlargement of regional organizations. But such a model of globalization has the contradiction that manifests itself in the fact that regional groupings obviously become economically more capable of self-preservation than the states that form them.

As mentioned earlier, the impression is created that the formation, enlargement and unification of regional integration organizations brings us closer to the final stage of the globalization, but at the same time in reality the establishment of regional integration blocs can segregate the countries inside this bloc to such an extend that their further integration with the other groupings or countries becomes more and more challenging, and it takes much more effort to carry forward that unification and to continue with integration even at the regional level, especially in comparison with the initial stage of the establishment of a regional integration organization.

Thus, the result of the process of formation of regional integration organizations may appear to be not practically feasible at a certain stage, when these organizations consider further integration not useful for their future sustainable development. 


\subsection{Disintegration in the processes of regionalization and globalization}

It is certainly true that integrating countries should fulfil some economic and political pre-conditions before entering into any stage of integration. The major preconditions are related to the healthy 'economic fundamentals' of their economies, their competitiveness, and their ability to stand up to consequences of restructuring processes. If disparities in economic development among integrating countries exist when they commence the integration process, barriers to successful integration could appear [17].

It should also be borne in mind that currently existing regional organizations may not only be integrated with the others, but also may fall apart or be divided into countries or some parts of those countries in order to further form other regional configurations.

Integration and disintegration are objectively interrelated processes. Moreover, disintegration forms the preconditions for integration on a new quantitative and qualitative basis. In some cases, conditions for reintegration may be created. The reintegration can be described as full, partial, or extended. In the first case, we are focusing on the renewal of this or that integration grouping with the previous composition of memberstates on the same political and economic grounds. Partial reintegration takes place when some members of integration groups are joined on the basis of previous principles or all participants, but on a qualitatively new basis. The extended integration is characterized by the inclusion of new members on a qualitatively new basis [21, p. 79].

Agreed disintegration means getting out of certain integration processes based on agreements between countries. This civilized, modern and legal mechanism provides an opportunity for all countries to prepare for changes in the rules and conditions of economic integration, minimizing objectively negative social, economic and political consequences (exit of the Baltic states from the free trade regime with Ukraine as a result of their accession to the EU, negotiations between the USA, Canada and Mexico on revision of the agreement on the formation of NAFTA/USMCA, etc.) [22, p. 8].

Brexit may serve as an example of the disintegration processes. Consequently, it proves the weakening of regional integration in the Western Europe, its fragmentation. At the same time, we cannot jump at the conclusion that it has led to the process of reverse globalization, to the fragmentation of the world economy; instead, there is all the evidence to state that there is more or less successful development of existing regional integration organizations in the modern world, as the indicators show in table 2.

For our purposes, it's important to draw the attention to the fact that the advancement of regional integration, its consistent transition from free trade agreement to full integration, results in the strengthening of the internal ties of the member states, and consequently - the weakening of their external ties, i.e. the economic relations with the third countries contributing to the segregation of the organization.
Table 2. GDP of the main regional integration blocs of the world (based on UNCTAD Handbook of Statistics 2016)*.

\begin{tabular}{|c|c|c|c|}
\hline \multirow[b]{2}{*}{$\begin{array}{c}\text { Regional blocs, stages } \\
\text { of the integration pro- } \\
\text { cess }\end{array}$} & \multicolumn{3}{|c|}{ GROSS DOMESTIC PRODUCT } \\
\hline & \begin{tabular}{|c|} 
Nominal \\
gross do- \\
mestic pro- \\
duct of the \\
regional in- \\
tegration \\
bloc, 2015, \\
millions of \\
dollars \\
\end{tabular} & \begin{tabular}{|c|} 
Regional \\
integration \\
bloc gross \\
domestic \\
product in \\
total world \\
domestic \\
product \\
$2015, \%$ \\
\end{tabular} & $\begin{array}{l}\text { Per capita no- } \\
\text { minal gross } \\
\text { domestic pro- } \\
\text { duct of the re- } \\
\text { gional integ- } \\
\text { ration bloc, } \\
2015 \text {, milli- } \\
\text { ons of dollars }\end{array}$ \\
\hline $\begin{array}{l}\text { 1. The European Uni- } \\
\text { on (EU), economic } \\
\text { and monetary union }\end{array}$ & 16067827 & 21,49 & 31686,7 \\
\hline $\begin{array}{l}\text { 2. Eurasian Economic } \\
\text { Union (EEU), eco- } \\
\text { nomic union }\end{array}$ & 1550510 & 2,07 & 8636,2 \\
\hline $\begin{array}{l}\text { 3. Association of So- } \\
\text { utheast Asian Nations } \\
\text { (ASEAN), free trade } \\
\text { area }\end{array}$ & 2453031 & 3,28 & 3879,5 \\
\hline $\begin{array}{l}\text { 4. South Asian Asso- } \\
\text { ciation for Regional } \\
\text { Cooperation } \\
\text { (SAARC), free trade } \\
\text { area }\end{array}$ & 2802915 & 3,75 & 1607,3 \\
\hline $\begin{array}{l}\text { 5. The Cooperation } \\
\text { Council for the Arab } \\
\text { States of the Gulf, ori- } \\
\text { ginally known as the } \\
\text { Gulf Cooperation Co- } \\
\text { uncil (GCC), customs } \\
\text { union }\end{array}$ & 1725744 & 2,31 & 32751,5 \\
\hline 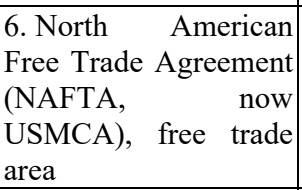 & 20648136 & 27,62 & 42266,7 \\
\hline $\begin{array}{lr}\text { 7. Southern } & \text { common } \\
\text { market (El Mercado } \\
\text { Comun del } & \text { Sur, } \\
\text { MERCOSUR), } & \text { cus- } \\
\text { toms union } & \\
\end{array}$ & 3504079 & 4,69 & 11982,1 \\
\hline $\begin{array}{l}\text { 8. Andean Community } \\
\text { of Nations (CAN), } \\
\text { customs union }\end{array}$ & 632204 & 0,85 & 5937,6 \\
\hline $\begin{array}{l}\text { 9. The Pacific Alliance } \\
\text { (Alianza del Pacifico, } \\
\text { AP), free trade area }\end{array}$ & 1874041 & 2,51 & 8344,9 \\
\hline $\begin{array}{l}\text { 10. East African Com- } \\
\text { munity (EAC), cus- } \\
\text { toms union }\end{array}$ & 154208 & 0,21 & 887,9 \\
\hline $\begin{array}{l}\text { 11. Common Market } \\
\text { for Eastern and Sou- } \\
\text { thern Africa (COME- } \\
\text { SA), customs union } \\
\end{array}$ & 613884 & 0,82 & 1418,6 \\
\hline $\begin{array}{l}\text { 12. Southern African } \\
\text { Development Commu- } \\
\text { nity (SADC), free tra- } \\
\text { de area }\end{array}$ & 608983 & 0,81 & 2444,3 \\
\hline $\begin{array}{l}\text { 13. Economic } \\
\text { munity of West } \\
\text { can }\end{array}$ & 663670 & 0,09 & 1900,8 \\
\hline
\end{tabular}


Since the enhancing of the internal ties in the balance of all the ties automatically weakens external ties, it leads to the weakening of the integrity, cohesion of the global economy, its deglobalization, and fragmentation.

And since globalization is to end up with the single planetary state creation, then during the globalization process the number of countries is to be reduced till the only one is left which is to be called a global state. However, we cannot state that the number of countries in the world is decreasing.

Theoretically, the regionalization process leads to the establishment of the regional state which substitutes the nation states. In this case, the regional state, replacing the nation states, reduces the number of countries in the world, thus contributing to the global economy formation. And if the process continues and the newly-formed complex regional states are united into bigger integration blocs, then the whole process leads to the creation of the single planetary state/global state.

Thus, we have defined the newly introduced and grounded notions of the regional state and the global/planetary state.

\subsection{Dialectical relationship between regionalization and globalization processes}

With the above-mentioned points in mind, we can conclude that, on the one hand, regionalization leads to deglobalization, since integration at the regional level improves the strengthening of unity at the local level, and the weakening of unity at the global level. However, on the other hand, the formation of a regional state dismantles the group of nation-states and strengthens the global unity.

The key point is that regionalization leads to globalization, to the reduction of the number of nationstates in the world, but under certain condition, namely when the formed regional grouping reaches the state of full integration and through a political treaty becomes a regional state instead of the totality of nation-states, on the basis of which it was created.

Finally, it can be argued that those processes of regionalization that are currently shaping the world economy, are actually limited by the concluded free trade agreements, established customs unions, common markets, etc., as it is shown in table 2. So, they, on the one hand, increase the overall efficiency of economic processes and enhance regional integration, but, on the other hand, do not substantially bring the world closer to political unity.

In summary, the strengthening of regionalization processes, that is, the increased segregation of the established and developed regional organizations, weakens the global cohesion of the world. Moreover, if the above-mentioned processes result in the political union - a regional state, conditions are created to unite these new complex regional states and thus move us closer to the time of formation of a single planetary state. It is important to underline, that the processes of regionalization, on the one hand, by the time they are completed and the political union is formed - a new regional state - are contributing to a single planetary state formation, and, on the other hand, they are weakening the unity of the world. But at the same time the unification of new regional powers strengthens the global cohesion of the world, given that such dynamics of regionalization development leads to a reduction of the number of states in the world through their unification.

Until the process of regionalization reaches the establishment of the new, more economically powerful regional state, it aims at reducing the unity of the world. But by completing this process, regionalization creates the conditions for a leapfrog to strengthen the unity of the world by uniting new powerful regional states. However, such powerful new regional states may not be interested in losing their independence and even decide to segregate or join some of the similar powerful new states to form separate unions. So, the above-mentioned detailed explanation helps to understand the logic behind the multipolar global world formation as opposed to the unipolar world maintaining.

An example of dialectical relationship between regionalization and globalization processes is the fate of the WTO. Regional trade agreements have increased in number, as well as complexity since the early 1990s. One of the most frequently asked questions is whether these regional groups help or undermine the WTO's multilateral trading system. In spite of the WTO position [24] that regional trade agreements can support the WTO's multilateral trading system, actually it seems that they compete with the WTO. The mere fact of regional trade agreements means the absence of uniform rules for world trade - the primary goal of the WTO. Blocking work of the main body of the WTO disputes settlement system - The Appellate Body - led to the emergence of proposals for the transfer of the consideration of trade disputes from the multilateral system to the system of bilateral trade agreements [25], thereby weakening the position of less powerful countries, leaving them face to face with stronger states.

In addition, along with the reluctance to take part in the processes of regionalization, one should take into account the possibility of an intention to leave the integration organization in case of some dissatisfaction with its functioning. Such a right, as well as the refusal to participate in further processes of regional integration, belongs to the status of the state irrespective of its economic and military power.

Clearly, any regional organization is initially based on the concept of the nation-state and then on the elaborated concept of the regional state, the sovereignty of which is derived from the sovereignty of the nationstates. Consequently, with the emergence of a regional state and its sovereignty, a new identity must emerge, which will replace the identities of the nation-states, and the aim of the regional state is to secure the interests of that new identity,

There is no need to prove that the most advanced integration bloc in the world, the EU, which has a welldeveloped system of supranational authorities, although is quite close to becoming the regional state and actually is approaching the status of a full-fledged federation, 
nevertheless has not been considered a regional state yet. In fact, the concept of a common identity, "European", for EU citizens of 28 countries has not appeared yet. Finally, Brexit and the euro area demonstrate that the EU ensures the rights of its member-states, the interests of which might conflict with those of the EU taken as a whole.

Thus, it is obvious that the globalization processes have reinforced positive and negative transformations on all the levels of the world economy but the main objective is to find the way to build on their advantages for the benefit of all the countries and regions of the world.

\section{Sustainable development of regions from global perspective}

Modern regionalism assumes the existence of four levels. The lower (local) level is the cross-border regional associations formed by the border territorialadministrative units of the neighboring countries, which create the so-called natural economic spaces.

At the local level, the most active interstate cooperation in the 1980-1990s was observed in Europe and East Asia. In Europe, cooperative associations emerged within the EU as a complement to subregional integration and as a means of deepening and optimizing it. The legal basis for these processes was the European (Madrid) Framework Convention on Transfrontier Cooperation between Territorial Communities which was adopted in 1989. By the end of the 1990s, there were more than 30 local cooperative entities integrated in Europe under the Border Regions Work Program. In Pacific Asia, the creation of local integration spaces (zones of economic growth) was in line with traditional for this part of the world non-institutional integration. Successful local economic cooperation projects include the Southern China Triangle (SCT), which includes the southern provinces of Guangdong and Fujian, Hong Kong and Taiwan.

The second level of modern regionalism is the most widespread category of regional integration organizations. The sub-regional entities represent different by the number of members groupings in one sub-regional zone. For example, in Europe - EFTA, in Latin America - MERCOSUR, in Africa - ECOWAS, etc.

The third, higher level of regionalism is formed by common regional economic groupings of a particular macro-region, such as the EU, ASEAN.

The example of the fourth level of regionalism is APEC as a transregional organization [4].

Classical theories of international cooperation and integration are rationalist and state-centered. Powerful states facilitate the emergence of regionalism in pursuit of economic and geopolitical interests. The United States, China, Russia, South Africa or Nigeria supported and engaged in region-building in order to strengthen military alliances, promote stability in neighboring countries, or secure access to new markets, cheap labour, water and energy resources [26]. So, the interregionalisation and trasregionalisation processes, along with the regionalization processes, are interrelated with the globalization processes as well.

At the same time transregional cooperation is promoted primarily by political factors, such as the wish of some states to play a greater role in global governance [27]. For example, the problem of strengthening two competitive blocs - Regional Comprehensive Economic Partnership and Transatlantic Trade and Investment Partnership in which China and the USA are trying to push their interests forward - may illustrate the point (some indicators are given in table 3 ).

Table 3. Regional comprehensive economic partnership and transatlantic trade and investment partnership.

\begin{tabular}{|c|c|c|}
\hline Indicators & RCEP & TTIP \\
\hline Population, mln, 2017 & 3604 & 838 \\
\hline GDP, mln dollars, 2015 & 22712154 & 33993080 \\
\hline Merchandise exports, mln dollars, 2017 & 5418089 & 7446853 \\
\hline Merchandise imports, mln dollars, 2017 & 4968072 & 8212786 \\
\hline
\end{tabular}

Practically, the current development of the interrelation between regionalization and globalization in the world economy indicates that various types of integration groups are being established (table 2), and the prospects of the two above-mentioned transregional organizations (table 3 ) are on the agenda, but it is doubtful that the integration organizations will become regional states in the near future.

To support this conclusion, let us see the dynamics of the most important economic indicator, GDP, presented in tables 4 and 5, which characterizes the development of the United States, the developed European countries (nearly the same compostion as that of the EU-28), and China during the period of 1980-2018.

Table 4. Dynamics of nominal GDP of the USA, Developed economies of Europe and China, mln dollars, 1980-2018.

\begin{tabular}{|l|r|r|c|}
\hline & \multicolumn{1}{|c|}{$\mathbf{1 9 8 0}$} & $\mathbf{1 9 9 0}$ & $\mathbf{2 0 0 0}$ \\
\hline World & 12273690 & 22951417 & 33299310 \\
\hline USA & 2877139 & 6010634 & 10347349 \\
\hline $\begin{array}{l}\text { Developed } \\
\text { economies: Europe }\end{array}$ & 4081450 & 7930384 & 9271785 \\
\hline China & 302943 & 396562 & 1208915 \\
\hline
\end{tabular}

\begin{tabular}{|l|c|c|c|c|}
\hline & $\mathbf{2 0 0 5}$ & $\mathbf{2 0 1 0}$ & $\mathbf{2 0 1 3}$ & $\mathbf{2 0 1 4}$ \\
\hline World & 47264846 & 65644956 & 76176342 & 78037088 \\
\hline USA & 13177635 & 15062761 & 16765686 & 17451747 \\
\hline $\begin{array}{l}\text { Developed } \\
\text { economies: Europe }\end{array}$ & 15068071 & 17986496 & 19231169 & 19755060 \\
\hline China & 2291432 & 6005388 & 9518402 & 10430590 \\
\hline
\end{tabular}

\begin{tabular}{|l|c|c|c|c|}
\hline & $\mathbf{2 0 1 5}$ & $\mathbf{2 0 1 6}$ & $\mathbf{2 0 1 7}$ & $\mathbf{2 0 1 8}$ \\
\hline World & 74752058 & 76365009 & 80452800 & 85323228 \\
\hline USA & 17925253 & 18664478 & 19490088 & 20600434 \\
\hline $\begin{array}{l}\text { Developed } \\
\text { economies: Europe }\end{array}$ & 17165290 & 17361225 & 18415260 & 19899297 \\
\hline China & 11156254 & 11386440 & 12020250 & 13605485 \\
\hline
\end{tabular}

Source: UNCTAD Handbook of Statistics 2016-2019.

As we can see (tables 5 and 6), since the 2000s China has begun to catch up with the United States and the 
developed European countries. It is necessary to underline that China transformed itself during the analyzed period from a weak developing economy into one of the three economic and political centers of the world.

Table 5. Dynamics of nominal GDP share of the USA, Developed economies of Europe and China, \%, 1980-2018.

\begin{tabular}{|c|c|c|c|c|c|c|c|}
\hline & & $\mathbf{1 9 8 0}$ & $\mathbf{1 9 9 0}$ & $\mathbf{2 0 0 0}$ & $\mathbf{2 0 0 5}$ & $\mathbf{2 0 1 0}$ & $\mathbf{2 0 1 3}$ \\
\hline 1 & USA & 23,44 & 26,18 & 31,07 & 27,88 & 22,95 & 22,01 \\
\hline 2 & $\begin{array}{c}\text { Developed } \\
\text { economies: Europe }\end{array}$ & 33,25 & 34,55 & 27,84 & 31,88 & 27,39 & 25,25 \\
\hline 3 & China & 2,47 & 1,73 & 3,63 & 4,85 & 9,15 & 12,49 \\
\hline 4 & $\mathbf{1 + 2}$ & 56,69 & 60,73 & 58,91 & 59,76 & 50,34 & 47,26 \\
\hline 5 & $\mathbf{3 / 1 + 2 , ~ \%}$ & 4,35 & 2,85 & 6,16 & 8,12 & 18,18 & 26,43 \\
\hline
\end{tabular}

\begin{tabular}{|l|c|l|l|l|l|l|}
\hline & & $\mathbf{2 0 1 4}$ & $\mathbf{2 0 1 5}$ & $\mathbf{2 0 1 6}$ & $\mathbf{2 0 1 7}$ & $\mathbf{2 0 1 8}$ \\
\hline 1 & USA & 22,36 & 23,98 & 24,44 & 24,23 & 24,14 \\
\hline 2 & $\begin{array}{c}\text { Developed economies: } \\
\text { Europe }\end{array}$ & 25,31 & 22,96 & 22,73 & 22,89 & 23,32 \\
\hline 3 & China & 13,37 & 14,92 & 14,91 & 14,94 & 15,95 \\
\hline 4 & $\mathbf{1 + 2}$ & 47,67 & 46,94 & 47,17 & 47,12 & 47,46 \\
\hline 5 & $\mathbf{3 / 1 + 2 , ~ \%}$ & 28,05 & 31,79 & 31,61 & 31,71 & 33,61 \\
\hline
\end{tabular}

Table 6. Per capita GDP of the USA, Developed economies of Europe and China in mln dollars, 1980-2018.

\begin{tabular}{|c|c|c|c|c|c|c|c|}
\hline & & $\mathbf{1 9 8 0}$ & $\mathbf{1 9 9 0}$ & $\mathbf{2 0 0 0}$ & $\mathbf{2 0 0 5}$ & $\mathbf{2 0 1 0}$ & $\mathbf{2 0 1 3}$ \\
\hline 1 & USA & 12355 & 23436 & 36078 & 43924 & 48018 & 52241 \\
\hline 2 & $\begin{array}{c}\text { Developed } \\
\text { economies: } \\
\text { Europe }\end{array}$ & 8838 & 16696 & 18522 & 29620 & 34763 & 36976 \\
\hline 3 & China & 310 & 343 & 952 & 1755 & 4478 & 6986 \\
\hline 4 & $\mathbf{3 / 1 , \%}$ & 2,5 & 1,46 & 2,64 & 4 & 9,33 & 13,37 \\
\hline 5 & $\mathbf{3 / 2 , \%}$ & 3,5 & 2,05 & 5,14 & 5,93 & 12,88 & 18.89 \\
\hline
\end{tabular}

\begin{tabular}{|c|c|r|r|r|r|r|}
\hline & & $\mathbf{2 0 1 4}$ & $\mathbf{2 0 1 5}$ & $\mathbf{2 0 1 6}$ & $\mathbf{2 0 1 7}$ & $\mathbf{2 0 1 8}$ \\
\hline 1 & USA & 53990 & 55059 & 57253 & 59421 & 62380 \\
\hline 2 & $\begin{array}{c}\text { Developed economies: } \\
\text { Europe }\end{array}$ & 37939 & 32924 & 33069 & 35010 & 37645 \\
\hline 3 & $\mathbf{3 . ~ C h i n a ~}$ & 7617 & 8107 & 8110 & 8525 & 9530 \\
\hline 4 & $\mathbf{3 / 1 , \%}$ & 14,11 & 14,72 & 14,17 & 14,35 & 15,28 \\
\hline 5 & $\mathbf{3 / 2 , \%}$ & 20,08 & 24,62 & 24,52 & 24,35 & 25,32 \\
\hline
\end{tabular}

Based on UNCTAD Handbook of Statistics 2016-2019.

It should be mentioned that on the background of negative impact of the world financial crisis of 20082010 China has proven to be one of the stable engines of globalization. Of course, the data shows that China's progress is impressive, but, in our opinion, it is hard to believe that China can be viewed as real competitor to the USA or the EU, especially if we pay attention to the dynamics of the per capita GDP as important socioeconomic indicator shown in table 6. Nevertheless, only due to the People's Republic of China the center of world progress started shifting from North America and Western Europe to the Asia Pacific Region.

We should take into account that China's foreign policy is aimed at achieving the status of a superstate until the middle of the 21 st century, and it looks like its global strategy "One belt, one road" will contribute to strengthening the position not only in Asia, but also in Europe and Africa. Under the conditions, it seems logical to expect both China and the USA to do their best in deepening integration ties with the EU-28 with the purpose of making their best for more effective functioning of their corresponding integration initiatives and/or establishing free trade areas (e.g., New Silk Road and Transatlatic Trade and Investment Partnership) but the EU will have to think carefully since it is challenging to take part it both integration organizations, expecially when China strongly supports free trade while the USA is focused on protectionism.

It's worth stressing that China is working at improving its trade ties (table 7) and is concluding as many free trade agreements as possible with various countries.

Table 7. Exports and imports of goods of China (100 mln US dollars).

\begin{tabular}{|c|c|c|c|}
\hline Years & Export & Import & Balance \\
\hline $\mathbf{1 9 7 8}$ & 97,5 & 108,9 & $-11,4$ \\
\hline $\mathbf{1 9 8 0}$ & 181,2 & 200,2 & $-19,0$ \\
\hline $\mathbf{1 9 8 5}$ & 273,5 & 422,5 & $-149,0$ \\
\hline $\mathbf{1 9 9 0}$ & 620,90 & 533,50 & 87,4 \\
\hline $\mathbf{1 9 9 5}$ & 1487,8 & 1320,8 & 167,0 \\
\hline $\mathbf{2 0 0 0}$ & 2492,0 & 2250,9 & 241,10 \\
\hline $\mathbf{2 0 0 5}$ & 7619,50 & 6599,5 & 1020,0 \\
\hline $\mathbf{2 0 1 0}$ & 15777,5 & 13962,4 & 1815,1 \\
\hline $\mathbf{2 0 1 1}$ & 18983,8 & 17434,8 & 1549,0 \\
\hline $\mathbf{2 0 1 2}$ & 20487,1 & 18184,1 & 2303,1 \\
\hline $\mathbf{2 0 1 3}$ & 22090,0 & 19499,9 & 2590,1 \\
\hline $\mathbf{2 0 1 4}$ & 23422,9 & 19592,3 & 3830,6 \\
\hline $\mathbf{2 0 1 5}$ & 22734,7 & 16795,6 & 5939,0 \\
\hline $\mathbf{2 0 1 6}$ & 20976,3 & 15879,3 & 5097,1 \\
\hline $\mathbf{2 0 1 7}$ & 22633,5 & 18437,9 & 4195,5 \\
\hline $\mathbf{2 0 1 8}$ & 24866,8 & 21357,3 & 3509,5 \\
\hline
\end{tabular}

Source: China Statistical Yearbook 2019. Foreign Trade and Economic Cooperation.11-2 Total Value of Imports and Exports of Goods. www.stats.gov.cn/tjsj/ndsj/2019/indexeh.htm

In general, experts continue to discuss the expansion of existing regional arrangements to include more countries, as well as the broadening and deepening of existing trade and investment liberalisation provisions.

In our opinion, the development path of all the regional integration aspirations should be used as a means of the consolidation of the world economy and should be directed in order to contribute to the balanced and sustainable development not only of the regions, but of the world [29]. On the one hand, scholars try to see sustainable future relating to the globalization level of world development while, on the other hand, many scientists innovate within the field of international studies, focusing on nation-state as the primary actor. We have shown the importance of all the three levels, paying special attention to the regional one. We agree with the specialists in world regions, who see the global phenomena through the lenses of myriad localities [30].

To conclude, the regional level plays significant role in supporting the balanced structure of the complex system of the world economy and is the key for the world's future sustainable functioning. 


\section{Conclusions}

Thus, the advancement of globalization processes results from the whole set of interactions of the integration processes, mainly at the regional level, and can occur in different ways, there are different scenarios for the development of global processes. Of fundamental importance here is the fact that at the global level, in order to preserve unity in diversity, a multipolar rather than a unipolar system must be formed to ensure the sustainable future for regions and the world.

\section{References}

1. The European idea. Historical events in the European integration process (1945-2014), http://www.cvce.eu. Accessed 25 Mar 2020

2. H. Patomaki, Disintegrative tendencies in global political economy: exits and conflicts (Routledge, . London, 2018)

3. K. Parthenay, A political sociology of regionalisms: perspectives for a comparison (Springer, 2019), p. 111

4. S. Pestsov, Comparative regionalism: typology of patterns of regional cooperation and integration. Russia and APR 2, 5-16 (2016)

5. A. Jones, Dictionary of Globalization (Polity, Cambridge, Malden, 2006), p. 258

6. R. Robertson, J.A. Scholte (eds.), Encyclopedia of Globalization, vol. 2 (Routledge, New York, London, 2007)

7. Ch. Chase-Dunn, Yu. Kawano, B.D. Brewer, Trade Globalization since 1795: Waves of Integration in the World-System, in Globalization and Economy, vol. 1. Globalizing Markets and Capitalism, ed. by P. James, B.K. Gills (Sage publications, Los Angeles, 2007), pp. 58-83

8. E. Rieger, S. Leibfried, Limits to globalization: welfare states and the world economy (Polity Press, Cambridge, 2009)

9. R. O'Rourke, M. Moodie, U.S. Role in the World: Background and Issues for Congress. Congressional Research Service (2019), p. 44

10. Enhancing mutual trust and cooperation to embrace an even better future of China-EU Relations, Speech by H. E. Wang Yi, State Councilor and Minister of Foreign Affairs of the People's Republic of China at the "Sixty-Minute Briefing" event of the European Policy Center, Brussels, 16 December 2019

11. B. Hettne, F. Soderbaum, Theorising the rise of regionness. New Political Economy 5(3), 457-472 (2000)

12. S. Sardak, S. Radziyevska, Yu. Prysiazhniuk, Civilizational structure of regional integration organizations. Przeglad Strategiczny 12, 59-79 (2019)

13. V. Dergachev, L. Vardomsky, Regional studies (Unity-Dana, Moscow, 2015)
14. B. Hettne, F. Soderbaum, The New Regionalism Approach. Politeia 17(3), 6-21 (1998)

15. N. Hamilton-Hart, Asia's new regionalism: government capacity and cooperation in the Western Pacific. Review of International Political Economy 10(2), 222-245 (2003)

16. I. Taylor, Globalization and regionalization in Africa: reactions to attempts at neo-liberal regionalism. Review of International Political Economy 10(2), 310-330 (2003)

17. J. Witkowska, Integration processes in the global economy: current state and prospects. The cases of the European Union, ASEAN Economic Community, and NAFTA. Comparative Economic Research 19(4), 47-65 (2016)

18. G.V. Kolodko, Globalization, transformation, crisis - what next? (Magistr, Moscow, 2016)

19. V.A. Schipkov, Regionalism as the ideology of globalism (MSUIR-University, Moscow, 2017)

20. K. Schwab, The Fourth Industrial Revolution (World Economic Forum, 2016)

21. L.B. Shostak, A.A. Oleshko, O.I. Dikarev, O.S. Badrak, International economic relations (National university for state tax service of Ukraine, Irpin, (2015)

22. A. Filipenko, O. Shnyrkov, D. Rusak, International Disintegration as a Component of the Geoeconomic Space: Theoretical and Methodological Research. Journal of Global Economy Review 8, 4-19 (2018)

23. UNCTAD Handbook of Statistics 2016, https://unctad.org/en/PublicationsLibrary/tdstat41_e n.pdf. Accessed 21 Mar 2017

24. Regionalism: friends or rivals? (2016), https://www.wto.org/english/thewto_e/whatis_e/tif_ e/bey1_e.htm. Accessed 25 Mar 2020

25. Commission proposes new tools to enforce Europe's rights in international trade (2019), https://ec.europa.eu/commission/presscorner/detail/e n/QANDA_19_6757. Accessed 25 Mar 2020

26. T.A. Borzel, Theorizing Regionalism: cooperation, integration, and governance, in Oxford handbook of comparative regionalism (Oxford University Press, Oxford, 2016)

27. K. Efremova, From regionalism to transregionalism: theoretic understanding of a new reality. Comparative Politics 2, 58-72 (2017)

28. UNCTAD Handbook of Statistics 2018, http://unctad.org/en/PublicationsLibrary/tdstat43_en .pdf. Accessed 25 Mar 2020

29. S. Sardak, S. Radziyevska, I. Us, Ukraine's exports as a global challenge for its future. CEUR Workshop Proceedings 2422, 84-99 (2019)

30. J.H. Mittelman, What's in a name? Global, international and regional studies. Globalizations 10(4), 515-519 (2013) 